\title{
Prosedur Kerja Perekam Medis dan Informasi Kesehatan dalam Masa Pandemi Covid-19 di Rumah Sakit
}

\section{Work Procedures For Medical Records and Health Information in the Covid-19 Pandemic Period at Hospitals}

\author{
Luthfiana Cahya Safitri ${ }^{1}$ \\ Arief Nabhan ${ }^{2}$ \\ Fatmawati $^{3}$ \\ Tatu Siti Husnul Khotimah ${ }^{4}$
}

1,2,3,4 Rumah Sakit Islam Fatimah Cilacap

Jl. Ir. H. Juanda No.20, Amiranom, Kebonmanis, Kec. Cilacap Utara, Kabupaten Cilacap

E-mail: Iuthfianacahya@gmail.com

\begin{abstract}
Personal protective equipment (PPE) is a set of safety tools used by workers to protect all or part of their body from possible exposure to potential hazards of the work environment to work-related accidents and diseases.Medical Record and Health Information Officers are at risk of being exposed to the Covid-19 virus. The Covid-19 virus that can survive in inanimate objects indirectly also have the potential to infect the medical recorder. This study aims to determine the working procedures of medical recorders during Covid-19 pandemic at the hospital based on the PORMIKI circular letter No.HM.01.01/002/III/2020. The method used in this research is descriptive research method using a qualitative approach. The sample in this study were all Medical Records and Health Information officers at hospital. The results showed that the work procedures for medical recorder during the Covid-19 pandemic at the hospital, starting from Personal Protective Equipment (PPE) for medical recorders and Health Information to maintenance procedures for the overall medical record of Covid19 patients. In accordance with work procedures recommended by PORMIKI in a circular.
\end{abstract}

Keywords: Personal Protection Equipment (PPE), Medical Records and Health Information, Work Procedur

\begin{abstract}
Abstrak
Alat Pelindung Diri (APD) merupakan seperangkat alat keselamatan yang digunakan oleh pekerja untuk melindungi seluruh atau sebagian tubuhnya dari kemungkinan adanya pemaparan potensi bahaya lingkungan kerja terhadap kecelakaan dan penyakit akibat kerja. Petugas Perekam Medis dan Informasi Kesehatan mempunyai resiko terhadap terpaparnya virus Covid-19. Petugas pendaftaran yang sering kontak langsung dengan pasien saat melaksanakan pendaftaran, serta virus Covid-19 yang dapat bertahan hidup di benda mati secara tidak langsung juga berpotensi menularkankepada petugas Perekam Medis dan Informasi Kesehatan. Penelitian ini bertujuan untuk mengetahui Prosedur Kerja Perekam Medis dan Informasi Kesehatan dalam Masa Pandemi Covid-19 di Rumah Sakit berdasarkan Surat edaran PORMIKI No.HM.01.01/002/III/2020. Metode yang digunakan dalam penelitian ini adalah metode penelitian deskriptif dengan menggunakan pendekatan kualitatif. Subjek dalam penelitian ini adalah seluruh petugas Rekam Medis dan Informasi Kesehatan di RS. Hasil penelitian menunjukan prosedur Kerja Perekam Medis dan Informasi Kesehatan di Masa Pandemi Covid19 di Rumah Sakit dari mulai Alat Pelindung Diri (APD) bagi petugas perekam medis dan Informasi Kesehatan hingga prosedur pemeliharaan rekam medis pasien Covid-19 secara keseluruhan telah sesuai dengan prosedur kerja PORMIKI dalam surat edaran.
\end{abstract}

Kata kunci: Alat Pelindung Diri (APD), Perekam Medis dan Informasi Kesehatan, Prosedur Kerja 


\section{A. Pendahuluan}

Coronavirus merupakan sebuah jenis penyakit baru yang ditemukan menyebabkan dan penyakit covid-19 sedangkan Covid-19 adalah penyakit menular yang disebabkan oleh jenis Coronavirus yang baru ditemukan. Virus baru dan penyakit yang disebabkan ini dikenal sejak dimulainya wabah di Wuhan, Tiongkok, bulan Desember 2019 yang menyebabkan meninggalnya ratusan ribu orang akibat terjangkit penyakit tersebut. Covid-19 ini sekarang menjawab sebuah pandemi yang terjadi di banyak negara di seluruh dunia tanpa terkecuali negara Indonesia (Asriati, 2020).

Negara Indonesia telah mencatat data terpapar coronavirus per tanggal 15 Februari 2021 mencapai 1.223.930 juta jiwa kasus kematian sebanyak 33.367 ribu jiwa. Rumah sakit yang merupakan garda terdepan rujukan dari pelayanan kesehatan lainnya harus selalu dalam keadaan siap siaga untuk penanganan kasus Covid-19 di Indonesia. Petugas kesehatan yang bekerja di rumah sakit merupakan salah satu kelompok berisiko tinggi terpapar penyakit COVID-19. Dokter dan perawat menjadi petugas paling rentan karena kontak langsung dengan pasien. Namun tenaga kesehatan di bidang lainnya juga berisiko terinfeksi Covid-19 jika tak sengaja terpapar virus di area bertugas (Alta Selina dkk, 2020).

Sebagaimana hasil sebuah penelitian telah disebutkan bahwa Covid-19 dapat bertahan di benda mati, secara tidak langsung juga berpotensi menularkan kepada seluruh petugas rumah sakit termasuk diantaranya petugas perekam medis. Baik yang bertugas dibagian pendaftaran pasien maupun dibagian pengelolaan berkas pasca pasien Covid-19 dirawat. Mengingat siklus hidup virus corona bisa bertahan maksimal 9 (sembilan) hari pada media kertas (Hasan, H. 2020).

Ketersediaan Alat Pelindung Diri atau sering disingkat dengan APD untuk tenaga kesehatan saat pandemi Covid-19 semakin sulit didapat. Alat Pelindung Diri (APD) merupakan seperangkat alat keselamatan yang digunakan oleh pekerja untuk melindungi seluruh atau sebagian tubuhnya dari kemungkinan adanya pemaparan potensi bahaya lingkungan kerja terhadap kecelakaan dan penyakit akibat kerja (Farsida \& Zulyanda, 2016). Pada pandemi Covid-19, APD tidak hanya digunakan oleh tenaga kesehatan tetapi juga oleh pasien dan masyarakat umum di seluruh negara yang terpapar virus ini. Kondisi tersebut memaksa tenaga kesehatan untuk menghemat penggunaan APD, seperti menggunakan APD seadanya serta melakukan pelayanan kesehatan dengan tanpa melepas APD dengan durasi lama. Kenyataan di lapangan masih banyak tenaga kesehatan yang belum secara maksimal melakukan penggunaan APD walaupun fungsinya sudah diketahui dan bahkan sudah disediakan.

Berkenaan dengan ketetapan World Health Organization (WHO) yang mengubah status kejadian infeksi Covid-19 dari Public Health Emergency of International Concern menjadi Pandemi. Ketua Umum perhimpunan organisasi perekam medis dan informasi kesehatan atau yang sering disebut dengan PORMIKI, telah menetapkan langkah-langkah lebih lanjut mengenai prosedur Kerja bagi Perekam Medis dan Informasi Kesehatan dalam situasi wabahvirus Covid-19 di berbagai wilayah serta mengantisipasi berbagai keadaan tidak kondusif yang mungkin terjadi 
dan mengancam keselamatan bagi para perekam Medis dan Informasi Kesehatan yang bertugas. Langkahlangkah ini diambil sebagai bentuk komitmen PORMIKI untuk meningkatkan kewaspadaan dan mengupayakan Perlindungan kepada seluruh Perekam Medis dan Informasi Kesehatan Indonesia dari Kontaminasi atau paparan Virus COVID-19. PORMIKI telah menetapkan langkah-Langkah Kewaspadaan dan Perlindungan kepada Perekam Medis dan Informasi Kesehatan dalam situasi wabah Infeksi virus Covid-19 dalam menjalankan pekerjaan rekam medis dan informasi kesehatan Berdasarkan kajian secara komprehensif dan seksama pada berbagai data dan informasi relevan, termasuk informasi update global infeksi Covid-19, pengalaman berbagai negara menghadapi penyebaran infeksi Covid-19 serta petunjuk dan pedoman yang diterbitkan oleh pemerintah Republik Indonesia yaitu Kementerian Kesehatan dan Kementerian Pendidikan dan Kebudayaan. Langkah tersebut telah tercantum dalam Surat Edaran PORMIKI No. HM.01.01/002/III/2020 tentang Prosedur Kerja Perekam Medis dan Informasi Kesehatan Dalam situasi Wabah Covid-19 yang diantaranya meliputi:

1. Prosedur Perlindungan Alat Pelindung Diri (APD) bagi Perekam Medis dan Informasi Kesehatan,

a. Bagi seluruh perekam medis dan informasi kesehatan dianjurkan untuk menggunakan APD selama menjalankan pekerjaan, minimal menggunakan :
1) Masker
(dianjurkan
menggunakan
masker
bedah) Sarung tangan

(dianjurkan menggunakan sarung tangan bedah)

2) Tersedia hand sanitizer dan selalu mencuci tangan baik dengan menggunakan sabun dan air mengalir ataupun hand sanitizer. Sebelum dan sesudah melakukan aktifitas

b. Bagi petugas pendaftaran perlu untuk diperhatikan hal berikut ini :

1) Pengisian formulir identitas pasien baru harap diisi oleh pasien atau keluarga pasien di meja khusus untuk pengisian formulir pasien baru. Atau lebih baik jika fasyankes sudah dapat memfasilitasi pendaftaran dengan menggunakan sistem online atau dapat disediakan komputer khusus untuk pasien atau keluarga pasien untuk mengisi identitas pasien baru.

2) Jarak antara petugas pendaftaran dan pasien adalah minimal 1 meter. Akan lebih baik jika ruang pendaftaran pasien diberikan penutup ruangan dari kaca yang diberikan lubang kecil sebagai alat komunikasi bertatap muka dan lubang untuk penyerahan formulir yang dibutuhkan pada saat pendaftaran.

2. Prosedur terhadap pemeliharaan berkas rekam medis

a. Rekam medis selama masa perawatan di rawat inap

1) Rekam medis selalu berada di ruang Nurse Station. 
2) Rekam medis tidak diperkenankan dibawa ke ruang perawatan pasien.

b. Rekam medis pasien pulang.

1) Rekam medis dimasukkan ke dalam plastik, disarankan untuk menggunakan plastik warna kuning (infeksi).

2) Rekam medis diserahkan ke unit rekam medis dan informasikesehatan

3) Masing-masing rekam medis tersebut di permukaan plastik berikan tanggal penerimaan rekam medis dengan menggunakan spidol atau alat tulis lainnya.

4) Dimasukan ke dalam box container atau box lainnya dan ditutup rapat

5) Disimpan di tempat khusus, jika memungkinkan

6) Diamkan selama 4-6 hari.

7) Sampul Rekam medis lap dengan alkohol SWAB/semprot cairan disinfektan dengan jarak tertentu agar kertas tidakrusak.

3. Hal-hal lain yang perlu untuk diperhatikan selama bertugas sebagai petugas perekam medis dan informasi kesehatan adalah sebagai berikut :

a. Hindari kontak langsung dengan pasien atau keluarga pasien,

b. Menjaga jarak pada saat berkomunikasi dengan pasien/keluarga pasien c. Hindari penggunaan alat kantor secara bersama-sama seperti alat tulis, kalkulator dan alat kantorlainnya

d. Biasakan mencuci tangan sebelum meninggalkan ruangan kerja dan memulai pekerjaan.

Rumah Sakit Islam Fatimah Cilacap merupakan salah satu rumah sakit yang menerima pasien covid-19. Berdasarkan studi pendahuluan di ketahui bahwa saat Pademi Rumah Sakit Islam Fatimah Cilacap menerima pasien covid-19 yang baru diketahui positif setelah melakukan pelayanan di Rumah Sakit tersebut serta terdapat petugas perekam medis yang positif virus Covid-19. Berdasarkan latar belakang diatas, maka rumusan masalah dalam penelitian ini adalah "Bagaimanakah Prosedur Kerja Perekam Medis dan Informasi Kesehatan dalam Masa Pandemi Covid-19 di Rumah Sakit Islam Fatimah Cilacap?" berdasarkan surat edaran PORMIKI.

\section{B. Metode}

Metode penelitian yang digunakan dalam penelitian ini yaitu metode penelitian deskriptif dengan menggunakan pendekatan kualitatif. Metode penelitian kualitatif adalah metode penelitian yang berlandaskan pada filsafat postpositivisme atau hasil observasi melalui berbagai macam metode, digunakan untuk meneliti pada kondisi objek yang alamiah, (sebagai lawannya adalah eksperimen) dimana peneliti adalah sebagai instrumen kunci, teknik pengumpulan data dilakukan secara triangulasi (gabungan), analisis data bersifat induktif / kualitatif, dan hasil penelitian kualitatif lebih menekankan makna daripada generalisasi (Sugiyono, 2017). 
Penelitian ini dilakukan pada Rumah Sakit Islam Fatimah Cilacap dengan proses pengumpulan data melalui observasi, dan wawancara kepada petugas rekam medis dan informasi kesehatan di rumah sakit tersebut. Analisis data dilakukan dengan reduksi data, penyajian data, dan pengambilan kesimpulan (Miles danHuberman, dalam Sugiyono, 2017).

\section{Hasil dan Pembahasan}

Rumah sakit Islam Fatimah Cilacap merupakan salah satu fasilitas pelayanan kesehatan rujukan Covid-19 di Kabupaten Cilacap, Jawa Tengah. Rumah sakit tipe kelas $C$ dengan akreditasi paripurna menyediakan 3 ruangan isolasi untuk pasien terkonfirmasi Covid-19 dengan jumlah tempat tidur lebih dari 69 bed ini telah melaksanakan

penanggulangan

prosedur pasien terkonfirmasi Covid-19 sejak bulan Mei 2020 lalu.

Petugas rekam medis dan informasi kesehatan di RS juga terdapat beberapa petugas yang telah ditugaskan untuk menjadi pengelola dokumen rekam medis pasien Covid-19 dengan tetap memperhatikan standar protokol kesehatan bagi petugas penanggulangan Covid-19. Namun dalam kenyataannya, masih ada beberapa petugas rekam medis dan informasi kesehatan yang bertugas di RS tidak memakai APD secara lengkap ataupun sesuai anjuran yang telah ditetapkan sehingga mengakibatkan empat orang petugas perekam medis yang positif terkonfirmasi Covid-19 dan harus menjalani isolasi di ruang isolasi RS.
Peneliti melakukan penelitian dengan berdasarkan surat edaran PORMIKI

No.HM.01.01/002/III/2020 tentang Prosedur Kerja Perekam Medis dan Informasi Kesehatan Dalam situasi Wabah Covid-19 disebutkan bahwa langkah-Langkah kewaspadaan dan perlindungan kepada Perekam Medis dan Informasi Kesehatan dalam situasi wabah infeksi virus Covid-19 dalam menjalankan pekerjaan rekam medis dan informasi kesehatan kepada beberapa subjek yang telah dipilih dan diperoleh hasil sebagai berikut:

Tabel 3.1 Penggunaan APD

\begin{tabular}{|l|l|c|c|}
\hline No & Variabel & $\begin{array}{c}\text { Mengguna- } \\
\text { kan }\end{array}$ & $\begin{array}{c}\text { Tidak } \\
\text { Mengguna- } \\
\text { kan }\end{array}$ \\
\hline 1 & Masker & $\mathrm{V}$ & \\
\hline 2 & $\begin{array}{l}\text { Sarung } \\
\text { Tangan }\end{array}$ & $\mathrm{V}$ & \\
\hline 3 & $\begin{array}{l}\text { Hand } \\
\text { Sanitizer }\end{array}$ & $\mathrm{V}$ & \\
\hline
\end{tabular}

1. Prosedur Perlindungan Alat Pelindung Diri (APD) bagi Perekam Medis dan Informasi Kesehatan:

a. Bagi seluruh perekam medis dan informasi kesehatan dianjurkan untuk menggunakan APD selama menjalankan pekerjaan, minimal menggunakan:

1) Masker (Dianjurkan menggunakan masker bedah). Penggunaan masker merupakan bagian dari rangkaian komprehensif langkah pencegahan dan pengendalian yang dapat membatasi penyebaran penyakit- penyakit virus saluran pernapasan tertentu, termasuk Covid-19. Masker dapat digunakan baik untuk melindungi orang yang sehat (dipakai untuk melindungi diri sendiri saat berkontak dengan orang yang terinfeksi) 
atau untuk mengendalikan sumber (dipakai oleh orang yang terinfeksi untuk mencegah penularan lebih lanjut)(WHO, 2020).

Berdasarkan hasil observasi yang telah dilaksanakan, diperoleh informasi bahwa petugas rekam medis di RSI Fatimah Cilacap secara keseluruhan telah menggunakan masker dalam menjalankan tugasnya. Namun tidak semua petugas memakaimasker bedah, ada beberapa petugas yang menggunakan masker berbahan dasar kain.

Petugas yang telah selesai sarapan Atau makan siang terkadang lupa untuk memakai maskernya kembali sehingga mereka bekerja tanpa menggunakan APD. Berdasarkan wawancara mendalam yang telah dilakukan diperoleh informasi bahwa sebagian dari mereka merasa sulit bernafas dan ingin menghirup udara dengan bebas tanpa terhalang oleh masker.

2) Sarung tangan (dianjurkan menggunakan sarung tangan bedah).

Sarung tangan medis digunakan oleh pekerja pelayanan kesehatan utamanya oleh karena dua alasan yaitu:

a) untuk mengurangi resiko kontaminasi tangan pekerja layanan kesehatan terhadap darah atau cairan tubuh lain dan

b) untuk mengurangi resiko penyebaran kuman ke lingkungan serta transmisi dari penyedia layanan kesehatan ke pasien dan sebaliknya, juga dari satu pasien ke pasien lain.

Sarung tangan medis sekali pakai, baik steril maupun non-steril biasanya terbuat dari senyawa alam karet lateks atau senyawa sintetik non-lateks seperti vinyl, nitril atau neoprene. Sarung tangan steril dibutuhkan untuk tindakan intervensional, namun beberapa tindakan nonintervensional juga membutuhkan pemakaian sarung tangan steril (Bayu \& Minhajat, 2015).

Berdasarkan

hasil

observasi, diperoleh informasi bahwa secara keseluruhan, petugas rekam medis di RS tidak menggunakan sarung tangan saat melaksanakan tugasnya tanpa terkecuali petugas penyimpanan berkas rekam medis. Namun berdasarkan hasil wawancara, diperoleh informasi bahwa tangan mereka merasa kegerahan sehingga kesulitan dalam mencari berkas rekam medis pada rak filing.

3) Tersedia hand sanitizer dan selalu mencuci tangan baik dengan menggunakan sabun dan air mengalir ataupun hand sanitizer. Sebelum dan sesudah melakukan aktifitas.

Hand sanitizer merupakan zat antiseptik dengan kandungan zat aktif berupa alkohol dan bahanantimikroba lain yang dapat menghambat pertumbuhan bakteri Gram positif dan Gram negatif pada tangan (Nugraheni \& Rini, 2018). 
Berdasarkan

hasil

observasi, diperoleh informasi bahwa di setiap ruang rekam medis RS telah tersedia hand sanitizer dan petugas rekam medis telah rutin melaksanakan cuci tangan sebelum ataupun sesudah melakukan aktivitas.

b. Bagi petugas pendaftaran perlu untuk diperhatikan hal berikut ini :

Tabel 3.2 APD Petugas Pendaftaran

\begin{tabular}{|c|l|c|c|}
\hline No & Variabel & $\begin{array}{l}\text { Diterap- } \\
\text { kan }\end{array}$ & $\begin{array}{c}\text { Tidak } \\
\text { Diterap- } \\
\text { kan }\end{array}$ \\
\hline 1 & $\begin{array}{l}\text { Pengisian } \\
\text { formulir }\end{array}$ & $\mathrm{V}$ & \\
\hline 2 & $\begin{array}{l}\text { Jarak 1m } \\
\text { antara } \\
\text { petugas } \\
\text { dan pasien }\end{array}$ & $\mathrm{V}$ & \\
\hline
\end{tabular}

1. Pengisian formulir identitas pasien baru harap diisi oleh pasien atau keluarga pasien di meja khusus untuk pengisian formulir pasien baru. Atau lebih baik jika fasyankes sudah dapat memfasilitasi pendaftaran dengan menggunakan sistem online atau dapat disediakan komputer khusus untuk pasien atau keluarga pasien untuk mengisi identitas pasien baru.

Berdasarkan hasil observasi diperoleh informasi bahwa, sistem pendaftaran pasien rawat jalan di RS dilakukan secara online yaitu Booking Online H-1 sebelum pelayanan di poliklinik melaluiSPORTIFC.

2. Jarak antar petugas pendaftaran dan pasien adalah minimal 1 meter.
Akan lebih baik jika ruang pendaftaran pasien diberikan penutup ruangan dari kaca yang diberikan lubang kecil sebagai alat komunikasi bertatap muka dan lubang untuk penyerahan formulir yang dibutuhkan pada saat pendaftaran.

Jaga jarak atau pembatasan sosial adalah pembatasan kegiatan tertentu penduduk dalam suatu wilayah. Pembatasan social ini dilakukan oleh semua orang di wilayah yang diduga terinfeksi penyakit. Pembatasan sosial dalam hal ini adalah jaga jarak fisik (physical distancing) (Ahyar, 2020).

Berdasarkan hasil observasi diperoleh informasi bahwa jarak pada tempat pendaftaran pasien rawat jalan antara pasien dengan petugas pendaftaran di RS telah sesuai anjuran yaitu terdapat sekat antara petugas dan pasien dengan jarak 1 meter dan terdapat lubang kecil dibawah sekat.

Namun, pada sistem pendaftaran pasien IGD atau Rawat Inap, saat pasien atau keluarga pasien mengisi formulir Persetujuan Umum/ General Consent dan edukasi Rawat Inap dilakukan di meja yang sudah disediakan di luar tanpa ada kaca penutup atau sekat antara pasien dan petugas pendaftaran sehingga rentan bagi petugas pendaftaran 
terinfeksi Covid-19.

Prosedur terhadap pemeliharaan berkas rekam medis

a. Rekam medis selama masa perawatan di rawat inap

1) Rekam medis selalu berada di ruang Nurse Station;

2) Rekam medis tidak diperkenankan dibawa ke ruang perawatan pasien.

b. Rekam medis pasien pulang

1) Rekam medis dimasukkan ke dalam plastik, disarankan untuk menggunakan plastik warna kuning (infeksi);

2) Rekam medis diserahkan ke unit rekam medis dan informasi kesehatan;

3) Masing-masing rekam medis tersebut di permukaan plastik berikan tanggal penerimaan rekam medis dengan menggunakan spidol atau alat tulis lainnya;

4) Dimasukan ke dalam box container atau box lainnya dan ditutup rapat;

5) Disimpan di tempat khusus, jika memungkinkan;

6) Diamkan selama 4-6 hari;

7) Sampul Rekam medis lap dengan alkohol SWAB / semprot cairan disinfektan dengan jarak tertentu agar kertas tidak rusak.

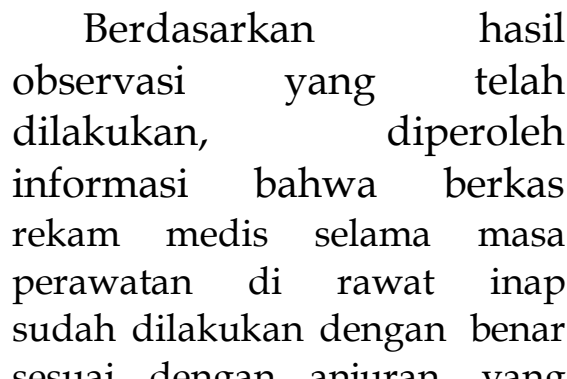
sesuai dengan anjuran yang diberikan PORMIKI, namun dalam pelaksanaan prosedur untuk berkas rekam medis pasien pulang tidakdimasukkan ke dalam kantong plastik warna kuning (infeksi) hanya dimasukan kedalam tas. Di Ruang Rekam Medis dokumen pasien Covid-19 hanya dimasukkan kedalam loker susun tanpa penutup oleh petugas admin ruangan karena tidak tersedianya box container. Berkas rekam medis pasien Covid-19 juga disimpan diruangan yang sama dengan berkas rekam medis rawat inap pasien non COVID - 19. Selain itu sampul berkas rekam medis tidak di lap dengan alkohol SWAB / semprot cairan desinfektan. 
3. Hal-hal lain yang perlu untuk diperhatikan selama bertugas sebagai petugas perekam medis dan informasi kesehatan adalah sebagai berikut :

Tabel 3.4 Hal- hal lain yang perlu diperhatikan

\begin{tabular}{|c|c|c|l|}
\hline No & Variabel & $\begin{array}{l}\text { Diterap } \\
\text { kan }\end{array}$ & $\begin{array}{l}\text { Tidak } \\
\text { diterapkan }\end{array}$ \\
\hline 1 & $\begin{array}{c}\text { Hindari } \\
\text { kontak } \\
\text { langsung }\end{array}$ & $\mathrm{V}$ & \\
\hline 2 & $\begin{array}{c}\text { Menjaga } \\
\text { jarak }\end{array}$ & $\mathrm{V}$ & \\
\hline & $\begin{array}{c}\text { Hindari } \\
\text { penggu- } \\
\text { naan alat } \\
\text { kantor } \\
\text { secara } \\
\text { bersama }\end{array}$ & $\mathrm{V}$ & \\
\hline 4 & $\begin{array}{c}\text { Biasakan } \\
\text { cuci } \\
\text { tangan }\end{array}$ & $\mathrm{V}$ & \\
\hline
\end{tabular}

a. Hindari kontak langsung dengan pasien atau keluarga pasien,

b. Menjaga jarak pada saat berkomunikasi dengan pasien / keluarga pasien

c. Hindari penggunaan alat kantor secara bersamasama seperti alat tulis, kalkulator dan alat kantor lainnya

d. Biasakan mencuci tangan sebelum meninggalkan ruangan kerja dan memulai pekerjaan.

Berdasarkan

hasil observasi, diperoleh informasi bahwa petugas Rekam Medis telah menjaga jarak dan menghindari kontak langsung dengan pasien sesuai dengan anjuran yang telah diberikan. Namun, di ruangan rekam medis petugas masih menggunakan alat kantor secarabersama-sama dan tidak semua ruangan rekam medis disediakan wastafel sehingga beberapa petugas rekam medis hanya menggunakan hand sanitizer saat sebelum dan setelah memulai pekerjaan.

D. Simpulan dan Saran

a) Simpulan

Berdasarkan uraian diatas dapat disimpulkan bahwa prosedur Kerja Perekam Medis dan Informasi Kesehatan di Masa Pandemi Covid-19 di Rumah Sakit Islam Fatimah Cilacap secara keseluruhan telah sesuai dengan prosedur kerja yang telah dianjurkan oleh PORMIKI dalam surat edaran.

1) Petugas rekam medis RSI Fatimah Cilacap telah menggunakan APD sesuai anjuran PORMIKI.

2) Pelaksanaan pendaftaran pasien di RS telah menggunakan sekat antara petugas pendaftaran dan pasien dengan jarak 1 meter.

3) Berkas rekam medis pasien Covid-19 selalu disimpan di nurse station namun pemeliharaan berkas pasien pulang belum sesuai dengan anjuran yang diberikan.

4) Petugas rekam medis di RSI Fatimah telah melakukan jaga jarak dan menghindari kontak langsung dengan pasien, serta membiasakan mencuci tangan sesuai anjuran yang diberikan PORMIKI. 
b) Saran

Bagi institusi dan pemerintah sebaiknya dapat meninjau peraturan kembali dengan disesuaikan pada standar yang berlaku dan kondisi di sekitar sehingga keamanan dan kenyamanan petugas saat melaksanakan tugasnya dapat terjamin keselamatannya. Bagi petugas rekam medis sebaiknya dapat lebih meningkatkan kesadaran diri akan pentingnya alat pelindung diri serta menjalankan protokol kesehatan dalam menjalankan tugasnya sehingga petugas dapat menjaga diri daripaparan virus Covid-19.

\section{E. Ucapan Terima Kasih}

Terima Kasih disampaikan kepada RS yang telah memfasilitasi dalam keberlangsungan penelitian ini. Terima kasih terutama kepada pihak-pihak yang telah membantu dalam pelaksanaan penelitian ini sehingga dapat diselesaikan tepat pada waktunya.

\section{F. Daftar Pustaka}

Ahyar, A. K. \& J. (2020). Pengaruh physical distancing dan social distancing terhadap kesehatan dalam pendekatan linguistik. Syntax Transformation, 21(1), 1-9.

Alta Selina, dkk. (2020). Studi Literatur Terkait Analisis Perilaku Kepatuhan Penggunaan Alat Pelindung Diri (APD) Pada Tenaga Kesehatan Saat Wabah Pandemi Corona Virus (Covid19).Jurnal Ilmiah Mahasiswa Vol.10 No.4: 105-110, Oktober 2020 ISSN: 2088-8961 https:/ / ejournal.undip.ac.id/ index.php/jim/index
Asriati. (2020). Beban Kerja Pelayanan Rekam Medis Di Masa Pademi Covid-19. Jurnal Manajemen Informasi dan Administrasi Kesehatan (JMIAK) ISSN: 2621-6612

Email:jmiakmedrec@gmail.com Volume 03 Nomor 02

November 2020 Halaman 44-49

Bayu \& Mihanjat. (2015). Keterampilan Sanitasi Tangan dan Penggunaan Sarung tangan. Fakultas Kedokteran Universitas Hasanuddin

Farsida \& Zulyanda,(2019). Analisis Penggunaan Alat Pelindung Diri Dalam Penanganan Sampah Medis Pada Petugas Cleaning Service Di Rsud Kabupaten Bekasi Tahun 2016. Jurnal Kesehatan Vol 12 No 1Tahun 2019 P-ISSN: 2086-2555; E-ISSN: 2622-7363

Hasan Hismawati, (2020). Panduan Penatalaksanaan Berkas Rekam Medis Terkait-Covid 19. Center of coding excellence www.coceonline.id/publikasi

Kementerian Kesehatan RI tentang perkembangan COVID-19 di Indonesia

Miles dan Huberman dalam Sugiyono, (2017). Metode penelitian kuantitatif, kualitatif, $D n$ RED. Bandung: cv Alfabeta

Nugraheni \& Rini. (2018). Uji Daya Hambat Berbagai Merek Hand Sanitize Gelterhadap Pertumbuhan Bakteri Escherichia coli dan Staphylococcus aureus. Journal of Pharmaceutical Science and Clinical Research, 2018, 01, 1826DOI:10.20961/jpscr.v3i1.15 380

Sugiyono. (2017). Metode penelitian kuantitatif, kualitatif, Dn RED. Bandung: cv Alfabeta 


\begin{tabular}{llr} 
Surat & \multicolumn{1}{c}{ Edaran PORMIKI } \\
& HM.01.01/002/III/2020 \\
& tentang Prosedur Kerja \\
& Perekam Medis dan Informasi \\
& Kesehatan Dalam situasi \\
& Wabah Covid-19 & \\
World & Health Organization (WHO). \\
& (2020). Anjuran mengenai \\
& penggunaan masker dalam \\
& konteks COVID-19
\end{tabular}

